\title{
The effects of performance criteria including accounting, market, and economy on the quality of financial reporting: A case study on Tehran Stock Exchange
}

\author{
Hossein Panahaian $^{a^{*}}$, and Mohammad Mahdi Hosseini ${ }^{\mathrm{b}}$
}

${ }^{a}$ Associate Professor, Islamic Azad University, Kashan Branch, Kashan, Iran

${ }^{b}$ Master Student of Accounting at the Islamic Azad University of Kashan Branch - Iran

\section{H R O N I C L E}

\section{Article history:}

Received June 2, 2012

Received in revised format

28 October 2012

Accepted 30 October 2012

Available online

November 72012

Keywords:

Quality of Financial Reporting

Mandatory Disclosure

Voluntary Disclosure

Tobin's Q

Market Value - Added

\section{Introduction}

Making appropriate decisions on the investment in economic enterprises as well as the optimal allocation of scarce resources in the society requires precise and comparable financial information. Such precise and comparable information is the essential factor for accountability and economic decisions made deliberately and a unique requirement for economic growth and development in private and public sector. Lack of information or false information may lead to economic underdevelopment and acts like a barrier to public prosperity.

The users of financial information especially investors require financial information for the sales and purchase of shares, evaluation of the performance of directors and making other economic decisions. Investors invest in an economic enterprise, when they have enough information of that enterprise. On

*Corresponding author. Tel: +989127573239

E-mail addresses: h.panahian@iaukashan.ac.ir (H. Panahaian) 
the other hand, the most important factor for making decisions by investors on purchase, sales, and acquisition of shares, profitability and performance of the related companies depend on reliable information. The criteria of accounting performance, market, and economy are reflected in the evaluation of the financial performance of any company. As the increase in the wealth of shareholders is the main purpose of business enterprises, each company must strive to increase the wealth of its shareholders by earning proper returns.

The disclosure of enough information is one of the most important issues, regarded as a source of trouble for accountants. Such information can be disclosed in different ways. The principle of disclosure is one of the accounting principles having effect on all aspects of financial reporting. The principle of disclosure requires that all important financial information and transactions of business enterprises are reported in a proper and complete manner.

Accordingly, main financial statements should contain all-important updated and related information, which is provided in a full and comprehensible form to pave the way for making decisions knowingly. On the other hand, the information provided should not be confusing in terms of quantity and quality for those who are willing to use such information. Complete disclosure requires that financial statements are designed and prepared to reflect the economic events of a fiscal period, more precisely. It must also contain the information suitable for retail investors. In other words, full disclosure principle states that no important information suitable for a normal investor becomes unavailable (Shroedr et al., 2009).

\section{Research Theoretical Framework}

According to recommendation no. 8 of Blue Ribbon' report issued in 1999 on the improvement of the efficiency of auditing committees of companies, "the committee suggests that auditing standards require independent auditors to provide the auditing committee with their judgments on the quality of the accounting principles applied for the preparation of financial statements of the related company for discussion. Such a discussion must be on the transparency of financial statements, the aggressiveness (optimism) and conservativeness (pessimism) of accounting principles and estimations as well as other managerial decisions applied for the preparation of financial statements audited by independent auditors. Such a requirement must be formulated in a flexible and standard language so that free negotiation and discussion are encouraged" (Nikomaram, \& Badavar Nahandi, 2009).

Accounting Principles Board stated in the declaration no. 22, "the Disclosure of Information on Accounting Policies", that all companies are required to disclose their accounting policies, and the method used for the exercise of such policies. In Principle, companies provide such information in "the summery of important accounting policies" inserted before the attached notes of financial statements (Shroedr et al., 2009).

The main purpose of the Accounting Principle Board of issuing the declaration no. 22 has been to provide information that helps investors compare different companies and industries with each other. As accounting policies affect deeply the values reported in financial statements, investors should be informed of such policies so that they can compare the financial statements of the various companies engaged in different industries. Access to such policies helps investors to decide on economic aspects more reliably, as they can compare companies more reasonably (Shroedr et al., 2009).

\section{Review of Literature}

Seyed Abadi (2004) studied the effects of financial ratios and size (the ratio of debt to equity and the ratio of profit before taxation to net sales) on the full disclosure of the financial statements of the companies listed on Tehran Stock Exchange. In this research, the disclosed information are extracted based on the accounting standards of Iran, and this shows the mandatory disclosure of information. The results of this research show that there is a significant relation between all above-mentioned variables and full disclosure. 
Arzitoon (2004) studied the relation of the characteristics of financial and functional structure of companies with the disclosure level of information in the financial statements of the companies listed on Tehran Stock Exchange. The results of this research show that there is a significant relationship between the characteristics of financial structure, size of company, ratio of debt to equity, and ratio of debt to total assets, and functional characteristics of companies, ratio of profit before taxation to net sales, ratio of profit before taxation to equity and sales amount.

Malekian (1997) conducted a research on the provision of annual reports and financial characteristics of the companies of Tehran Stock Exchange. His aimed to formulate standards on financial reporting field in Iran. In this research, Malekian formulated a control list on the disclosure items by the study of intentional accounting standards, disclosure items in the developed countries and developing ones, disclosure items in the publications of auditing organization, financial statements of Tehran stock exchange, reports of the companies in Iran and Iranian commercial laws based on the commercial and economic environment and provided this list in form of a questionnaire to three groups of accounting scholars, financial management and financial analysts, who were requested to determine the relative importance of the disclosure items by giving them scores from 1 to 5. After such a scoring obtained from all three groups, the weighted mean of three groups for each disclosure items has been calculated.

Those disclosure items with the mean of 3 and higher values were selected as the information that must be disclosed by companies. Thereafter, the disclosure list has been compared with the annual reports of 48 companies listed on Tehran Stock Exchange, which were taken as samples. By such a comparison, the comprehensiveness of such a disclosure has been determined for each company. If the related company observed the disclosure items, it was scored by 1 , and in case of failure in such an observance, it was received the score of zero. In cases that the disclosure item was not applicable, no score was given. The results indicated that there was a significant relationship between the size of company (total assets) and full disclosure of annual reports, a significant relationship between the ratio of debt to equity and full disclosure of annual reports, a significant relation between the net sales and full disclosure of annual reports, a relationship between the ratio of profit before taxation to equity and full disclosure of annual reports and a relation between the ratio of profit before taxation to sales and full disclosure of annual reports.

Wallace et al. (1994) studied the effects of corporate size, debt ratio, profit, return on equity, liquidity, auditing company, registration status in share market, and type of industry on disclosure. The findings of this research showed that bigger companies were more able to provide information, which was more comprehensive. Moreover, the companies, registered in the stock exchange of Madrid and Valencia, were desirous to prepare and disclose more information and they reported that there was a negative relation between liquidity and disclosure.

Wallace et al. (1995) studied the effects of corporate size, ratio of debt to liquidity, profit margin, return on equity, liquidity, auditing company, ownership dispersion and type of industry on disclosure. The results of this research showed that the index of disclosure was in a positive relationship to the size of company. Moreover, it must be noted that the index of disclosure has a negative relation to the profits of company, and size of auditing company.

Nasser et al. (2002) studied the effects of the number of shareholders, corporate size, auditing company's size, return on equity, liquidity, profit margin, type of industry, domestic and foreign ownership on disclosure. The results of this research showed that the size of company, size of auditing company, return on equity, and profit margin had a negative relation to the depth of disclosure of information.

Khalil al-Said (2006) studied the effects of corporate size, debt ratio, ownership dispersion, age of company, profit margin, return on equity, type of industry, and type of auditing company on disclosure. The results of this research showed that the median of disclosure index was less than its mean. Moreover, the findings of this research showed that the size of company had a significant 
relationship with the level of disclosure; while, other variables had no role in the level of voluntarily disclosure.

Wallace et al. (1994) conducted an empirical research on the relationship between the comprehensiveness of annual reports of companies and the characteristics of such companies in Spain. The list of disclosure items was limited to 16 items that disclosed in Spain accounting system compulsorily. They prepared a list, in which the expected details of each selected item of disclosure were reflected. This list provided both qualitative and quantitative information. Qualitative information can be traced in managerial analyses, notes attached to the annual reports, and even accounts.

These researchers studied the information set forth in the reports of the year 1991 of fifty sampled companies. In this research, 30 reports of the companies listed on the both stock exchanges of Valencia and Madrid, as well as 20 reports of the companies not listed in the same stock exchanges are studied. In this research, the following results are obtained using the statistical tests of multivariate regression (rank OLS):

o The sampled companies with higher leverage are more interested in higher level of disclosure, and those ones with lower leverage are interested in contrast to disclose little information in their annual reports.

o The sampled companies with higher performance (return on equity and profit margin) and higher liquidity (current ratio) are interested to disclose little information.

o The companies listed on Madrid and Valencia Stock Exchanges are interested to disclose more information than what is disclosed by the companies not listed on these stock exchanges.

\section{Research Hypotheses}

The main hypothesis of this research is as follows:

There is a relation between performance criteria (including accounting, market and economic criteria) and the quality of financial reports.

The secondary hypotheses of this research are classified in the following four items:

1) There is a relation between the rate of return on equity and the level of mandatory disclosure (of the audited financial statements).

2) There is a relation between Tobin's $Q$ and the level of mandatory disclosure (of the audited financial statements).

3) There is a relation between the rate of return on equity and level of mandatory disclosure (of the audited financial statements).

4) There is a relation between market value-added and level of mandatory disclosure (of the audited financial statements).

\section{Research Method}

The method used in this research is of descriptive - analytical type based on the analysis of panel data. This research, which is an applied one in terms of its objective, uses correlation tests and regression of panel data with fixed effects for the analysis of data, and for such a purpose, it uses EViews application software. 


\subsection{Statistical Population and Sample}

The statistical population of this research consists of the companies listed on Tehran Stock Exchange for the period of five years from 2006 to 2011. To calculate the members of an ideal statistical population, those companies with the following conditions are selected:

- $\quad$ The fiscal year of the selected companies must be ended to March 19.

- The selected companies are not of holding or investment types.

- The equity of such companies must not be reported negative.

Considering the above-mentioned limits, 190 companies are selected as the members of the statistical population of this research. In addition to the random sampling, the related sample must be so big that the results of the tests could be generalized. For this purpose, Cochran's formula has been applied to calculate the volume of the statistical sample. According to Cochran's formula, 99 companies are selected as the members of this sample taken based on stratified random method and stratified simple method at the next stage.

\subsection{Measurement of Research Variables}

The Quality of Financial Reporting: In this research, the level of disclosure is measured using the index introduced by the journal of the Auditing Organization (sampled financial statements), and disclosure checklist prescribed by the Iranian Association of Certified Public Accountants.

For measuring the level of disclosure, any company observing the prescribed level of disclosure receives the score 1 and in case of failure in such an observance, it receives zero. In cases, that scoring is not applicable no score is given. Accordingly, the mandatory level of disclosure of each company is defined as the ratio of the scores given to the disclosed items to the total items, which must be disclosed. This index lacks indeed the measurement weight of disclosure. This approach has been applied in the researches of Tai et al. (1990), Ahmed and Nicholls (1994), Wallace \& Nasser, 1995, Jaggi, \& Law, 2000)

In the Table 1, the methods of measuring variables and the symbols used for them are listed:

\section{Table 1}

Method of Measuring the Variables and the Symbols used in the model

\begin{tabular}{|c|c|c|c|c|c|}
\hline No. & Criterion & Type of Variable & Studied Variable & Symbol & Method of Calculation \\
\hline 1 & Accounting & Independent & Equity & ROI & $\mathrm{ROE}=\frac{\text { Net Profit }}{\text { equity }}$ \\
\hline 2 & Accounting & Independent & Earnings per Share & EPS & $\mathrm{EPS}=\frac{\text { net profit }}{\text { Number of corporate Shares }}$ \\
\hline 3 & Market & Independent & Tobin's Q & Tobin-Q & $\begin{array}{c}\text { Tobin } \mathrm{Q}=\text { Corporate Market Value } \\
\text { Corporate Office Value }\end{array}$ \\
\hline 4 & Economic & Independent & $\begin{array}{l}\text { Market Value- } \\
\text { added }\end{array}$ & MVA & MVA = Share Market Value - Equity \\
\hline 5 & --- & Dependent & $\begin{array}{l}\text { Mandatory Level } \\
\text { of Disclosure }\end{array}$ & MDQ & $\mathrm{MDQ}=\frac{\text { Disclosed Items }}{\text { Items required to be disclosed }}$ \\
\hline
\end{tabular}

\subsection{Research Model}

To study the effects of the criteria used for the evaluation of accounting, market, and economic performance on the mandatory disclosure of information, the following model has been prepared:

$M D Q=\beta_{0}+\beta_{1} R O I+\beta_{2} E P S+\beta_{3}$ Tobin $-Q+\beta_{4} M V A+\varepsilon$,

where all variables in Eq. (1) are introduced in Table 1, $\beta_{0}$ to $\beta_{4}$ are coefficients of regression model, which are estimated using ordinary least square technique.

\subsection{Calculation of Central and Dispersion Parameters}

At this stage, the quantities of the descriptive statistics of the dependent variable and independent variables including mean, median, maximum, and minimum are calculated: 
Table 2

Descriptive Statistics of All Companies: 2006-2011

\begin{tabular}{cccccccccc}
\hline Item & Variable & $\begin{array}{c}\text { No. of } \\
\text { Observations }\end{array}$ & Mean & Median & Max. & Min. & $\begin{array}{c}\text { Standard } \\
\text { Deviation }\end{array}$ & $\begin{array}{c}\text { Jarque-Bera } \\
\text { Test }\end{array}$ & $\begin{array}{c}\text { Prob. } \\
\text { 1 }\end{array}$ \\
\hline MDQ & 495 & 0.837 & 0.85 & 0.98 & 0.59 & 0.06 & 1.032 & 0.325 \\
2 & ROE & 495 & 0.371 & 0.36 & 1.02 & 0 & 0.185 & 1.254 & 0.459 \\
3 & EPS & 495 & 1205.7 & 984.1 & 7171 & 2 & 1284 & 2.32 & 0.897 \\
4 & MVA & 495 & 1.19 & 1.82 & 4.57 & 1.16 & 4.17 & 1.48 & 0.521 \\
5 & Tobin Q & 495 & 2.27 & 1.92 & 8.49 & 0 & 1.21 & 1.032 & 0.237 \\
\hline
\end{tabular}

\subsection{Description of Findings}

The procedures used for the estimation and test of the assumptions of panel regression model in all companies lead to the formation of different algorithms. In the study of the companies, F test confirmed the relevance of the period fixed-effects panel data regression. In other words, this regression is applied in this model, since there has been no other choice for the estimation procedure of the model.

To reduce the problems of inefficiency arising out of the heterogeneity and autocorrelation of the fiscal periods, the robust standard deviation of the panel regression coefficients are calculated using period SUR. For this purpose, period fixed-effects regression model is selected by F test.

To estimate the model, it is required to be sure of the reliability of the results. Therefore, the assumptions of panel regression have been studied, and the homoscedasticity of variances is tested by White test and Glejser test.

The normality of the distribution of regressions residuals has been studied using Jarque -Bera test. Thereafter, complex variables are used to increase the likelihood of such normality. To test the colinearity of the variables, the log-linear relation of the variables has been studied. Moreover, first difference method has been applied to remove the autocorrelation of the variables. In conclusion, the results of Jarque - Bera test show that JB statistic is equal to 1.04 and the value of prob. Equal to 0.592. Therefore, the null hypothesis, stating that the distribution of error terms is normal at the alpha level of $5 \%$, is not rejected.

\subsection{The Analysis of the Relation of Performance Criteria (Accounting, Market, and Economy) with the Quality of Financial Reporting}

To estimate the model, at first the time-fixed effects are calculated. In this model, an intercept elevation has been assigned to each year (from 2006 to 2011). To determine if these intercept elevations are significantly different in terms of statistics, Chow test is used. The results of this test show that the null hypothesis, stating that the intercept elevations are equal, is rejected. Therefore, fixed-effect model is not selected at this stage as the preferred model. It is required that fixed-effect model is tested in comparison to the random-effects model. For this purpose, Hausman test is applied. The results of Hausman test show that null hypothesis stating that there is a relation between the effects of variables is not rejected. As a result, the preferred model for testing the above-mentioned hypotheses is the random-effects panel regression model.

The results obtained from the model show that there is a significant relation between the variables mandatory disclosure index (MDQ) and earnings per share, and the value of beta at the alpha level of five percent is of significance, as the value of prob. is less than 0.05. Moreover, the results show that there is a relation between mandatory disclosure index (MDQ) and market value-added, and the value of prob. at the alpha level of five percent is of significance. There is also a significant relation between mandatory disclosure index (MDA) and the rate of return on equity (ROE). It is also shown that there is no significant relation between the ratio of market value of company to its office value (Q-Tobin) and the mandatory disclosure index (MDQ). 
Table 3

The Results of Regression Test of the Main Hypothesis based on E-View Application

\begin{tabular}{ccccc}
\hline Variable & Coefficient & Std. Error & t-Statistic & Prob. \\
\hline MVA & $-7.06 \mathrm{E}-16$ & $5.86 \mathrm{E}-16$ & -1.205640 & 0.0228 \\
ROE & 0.006873 & 0.006882 & 0.998670 & 0.0318 \\
EPS & $8.30 \mathrm{E}-07$ & $2.36 \mathrm{E}-06$ & 0.351908 & 0.0272 \\
QTOBIN & $-3.25 \mathrm{E}-06$ & 0.001663 & -0.001955 & 0.9984 \\
C & 0.829496 & 0.006622 & 125.2604 & 0.0000 \\
\hline \multicolumn{5}{c}{ Weighted statistics } \\
\hline R-squared & Adj. R-squared & Durbin-Watson stat & F-Statistic & Prob. \\
0.106321 & 0.091611 & 2.000595 & 7.227463 & 0.00000 \\
\hline
\end{tabular}

The results of fitting the model show that the value of $R^{2}$ is equal to 0.106 . In other words, 10.6 percent of the changes in the index of mandatory disclosure in the companies listed on the stock exchange can be explained by the independent variables of the model. Considering the value of S.E. in proportion to S.D., it can be claimed that regression line has been drawn well, and the dispersion of data is of low value. Durbin - Watson statistic, which is equal to 2.00 , indicates that there is no autocorrelation in the model.

In the above-mentioned model, the function of the test conducted on the sample $(F=7.22)$ show that the value of $\mathrm{F}$ at the alpha level of five percent is significant, and therefore, null hypothesis is rejected. As a result, it can be claimed that the value of $R^{2}$ is statistically significant.

\subsection{The Analysis of the Relation of the Rate of Return on Equity and the Quality of Financial Reporting}

To estimate the model, at first the time-fixed effects are calculated. In this model, an intercept elevation has been assigned to each year (from 2006 to 2011). To determine if these intercept elevations are significantly different in terms of statistics, Chow test is used. The results of this test show that the null hypothesis, stating that the intercept elevations are equal, is rejected. Therefore, fixed-effect model is not selected at this stage as the preferred model. It is required that fixed-effect model is tested in comparison to the random-effects model.

For this purpose, Hausman test is applied. The results of Hausman test show that null hypothesis stating that there is a relation between the effects of variables is not rejected. As a result, the preferred model for testing the above-mentioned hypotheses is the random-effects panel regression model. The results obtained from the model show that there is a significant relation between the variables mandatory disclosure index (MDQ) and the rate of return on equity, and the value of beta at the alpha level of five percent is of significance, as the value of prob. is less than 0.05 . The results of fitting the model show that the value of $R^{2}$ is equal to 0.103 . In other words, 10.3 percent of the changes in the index of mandatory disclosure in the companies listed on the stock exchange can be explained by the rate of return on equity. Considering the value of S.E. in proportion to S.D., it can be claimed that regression line has been drawn well, and the dispersion of data is of low value. Durbin - Watson statistic, which is equal to 2.03, indicates that there is no autocorrelation in the model. In the abovementioned model, the function of the test conducted on the sample $(F=11.24)$ shows that the value of $\mathrm{F}$ at the alpha level of five percent is significant, and therefore, null hypothesis is rejected.

\section{Table 4}

The Results of the Regression Test of the First Sub-Hypothesis based on E-Views

\begin{tabular}{ccccc}
\hline Variable & Coefficient & Std. Error & t-Statistic & Prob. \\
\hline ROE & 0.007727 & 0.005579 & 1.385045 & 0.0382 \\
C & 0.829400 & 0.006017 & 137.8540 & 0.0000 \\
\hline R-squared & Adj. R-squared & Weighted statistics & \\
0.103118 & 0.093948 & Durbin-Watson stat & F-Statistic & Prob. \\
\hline
\end{tabular}


Considering the effective variables in the model and multivariate regression, it is inferred that the direction of the test is positive. According to the coefficient of determination $\left(R^{2}\right)$, distribution tends to zero. Therefore, the relation between the rate of return on equity and mandatory disclosure index of the companies listed on the stock exchange is insignificant. In other words, about 10.3 percent of the changes between the quality of disclosure and the rate of return on equity have been estimated.

\subsection{The Analysis of the Relation between Earnings per Share and the Quality of Financial Reporting}

To estimate the model, at first the time-fixed effects are calculated. In this model, an intercept elevation has been assigned to each year (from 2006 to 2011). To determine if these intercept elevations are significantly different in terms of statistics, Chow test is used. The results of this test show that the null hypothesis, stating that the intercept elevations are equal, is rejected. Therefore, fixed-effect model is not selected at this stage as the preferred model. It is required that fixed-effect model is tested in comparison to the random-effects model. For this purpose, Hausman test is applied. The results of Hausman test show that null hypothesis stating that there is a relation between the effects of variables is not rejected. As a result, the preferred model for testing the above-mentioned hypotheses is the random-effects panel regression model.

The results obtained from the model show that there is a significant relation between the variables mandatory disclosure index (MDQ) and earnings per share (EPS). The value of beta at the alpha level of five percent is of significance, as the value of prob. is less than 0.05 . The results of fitting the model show that the value of $r^{2}$ is equal to 0.096. In other words, 9.6 percent of the changes in the mandatory disclosure index of the companies listed on the stock exchange can be explained by the earnings per share.

Considering the value of S.E. in proportion to S.D., it can be claimed that regression line has been drawn well, and the dispersion of data is of low value. Durbin - Watson statistic, which is equal to 2.00 , indicates that there is no autocorrelation in the model. In the above-mentioned model, the function of the test conducted on the sample $(F=10.42)$ shows that the value of $F$ at the alpha level of five percent is significant, and therefore, null hypothesis is rejected.

\section{Table 5}

The Results of the Regression Test of the Second Sub-Hypothesis based on E-Views

\begin{tabular}{|c|c|c|c|c|}
\hline Variable & Coefficient & Std. Error & $\mathrm{t}$-Statistic & Prob. \\
\hline EPS & $1.55 \mathrm{E}-06$ & $1.94 \mathrm{E}-06$ & 0.799264 & 0.0279 \\
\hline $\mathrm{C}$ & 0.830459 & 0.006022 & 137.8993 & 0.0000 \\
\hline \multicolumn{5}{|c|}{ Weighted statistics } \\
\hline R-squared & Adj. R-squared & Durbin-Watson stat & F-Statistic & Prob. \\
\hline 0.096349 & 0.087110 & 2.004326 & 10.42768 & 0.00000 \\
\hline
\end{tabular}

Considering the effective variables in the model and multivariate regression, it is inferred that the direction of the test is positive. According to the coefficient of determination $\left(R^{2}\right)$, distribution tends to zero. Therefore, the relationship between earnings per share and mandatory disclosure index of the companies listed on the stock exchange is insignificant. In other words, about 9.6 percent of the changes between the quality of disclosure and earnings per share have been estimated.

\subsection{The Analysis of the Relation between Tobin's Q and the Quality of Financial Reporting}

To estimate the model, at first the time-fixed effects are calculated. In this model, an intercept elevation has been assigned to each year (from 2006 to 2011). To determine if these intercept elevations are significantly different in terms of statistics, Chow test is used. The results of this test show that the null hypothesis, stating that the intercept elevations are equal, is rejected. Therefore, fixed-effect model is not selected at this stage as the preferred model. It is required that fixed-effect model is tested in comparison to the random-effects model. For this purpose, Hausman test is applied. The results of Hausman test show that null hypothesis stating that there is a relation between the 
effects of variables is not rejected. As a result, the preferred model for testing the above-mentioned hypotheses is the random-effects panel regression model.

The results obtained from the model show that there is no significant relation between the variables mandatory disclosure index (MDQ) and the ratio of corporate market value to its book value (QTOBIN). The value of beta at the alpha level of five percent is insignificant, since the value of prob. is greater than 0.05. The results of fitting the model show that the value of $r^{2}$ is equal to 0.097 . In other words, 9.7 percent of the changes in the mandatory disclosure index of the companies listed on the stock exchange can be explained by the ratio of the market value of the company to its office value (QTOBIN).

\section{Table 6}

The Results of the Regression Test of the Third Sub-Hypothesis based on E-Views

\begin{tabular}{ccccc}
\hline Variable & Coefficient & Std. Error & t-statistic & Prob. \\
\hline QTOBIN & -0.000129 & 0.001563 & -0.082227 & 0.9345 \\
C & 0.832108 & 0.006419 & 129.6361 & 0.0000 \\
\hline R-squared & Adj. R-squared & Weighted statistics & \\
0.097303 & 0.088073 & 2.003770 & F-Statistic & Prob. \\
\hline
\end{tabular}

Considering the value of S.E. in proportion to S.D., it can be claimed that regression line has been drawn well, and the dispersion of data is of low value. Durbin - Watson statistic, which is equal to 1.97, indicates that there is no autocorrelation in the model. In the above-mentioned model, the function of the test conducted on the sample $(\mathrm{F}=10.54)$ shows that the value of $\mathrm{F}$ at the alpha level of five percent is insignificant, and therefore, null hypothesis is not rejected.

Considering the effective variables in the model and multivariate regression, and the coefficient of determination $\left(R^{2}\right)$, distribution tends to zero. Therefore, the relation between QTOBIN and mandatory disclosure index of the companies listed on the stock exchange is insignificant.

According to this model, it can be inferred that the ratio of corporate market value to corporate office value (QTOBIN) has no effect on the mandatory disclosure level of the companies listed on the stock exchange.

\subsection{The Analysis of the Relation between Market Value-Added and the Quality of Financial Reporting}

To estimate the model, at first the time-fixed effects are calculated. In this model, an intercept elevation has been assigned to each year (from 2006 to 2011). To determine if these intercept elevations are significantly different in terms of statistics, Chow test is used. The results of this test show that the null hypothesis, stating that the intercept elevations are equal, is rejected. Therefore, fixed-effect model is not selected at this stage as the preferred model.

It is required that fixed-effect model is tested in comparison to the random-effects model. For this purpose, Hausman test is applied. The results of Hausman test show that null hypothesis stating that there is a relation between the effects of variables is not rejected. As a result, the preferred model for testing the above-mentioned hypotheses is the random-effects panel regression model.

\section{Table 7}

The Results of the Regression Test of the Fourth Sub-Hypothesis based on E-Views

\begin{tabular}{ccccc}
\hline Variable & Coefficient & Std. Error & t-statistic & Prob. \\
\hline MVA & $-8.48 \mathrm{E}-16$ & $5.58 \mathrm{E}-16$ & -1.520038 & 0.0604 \\
C & 0.832569 & 0.005820 & 143.0508 & 0.0000 \\
\hline R-squared & Adj. R-squared & Weighted statistics & \\
0.100391 & 0.091192 & 1.992449 & F-Statistic & Prob. \\
\hline
\end{tabular}


The results obtained from the model show that there is a significant relation between the variables mandatory disclosure index (MDQ) and market value-added. The value of beta at the alpha level of ten percent is of significance, as the value of prob. is less than 0.10 .

The results of fitting the model show that the value of $R^{2}$ is equal to 0.10 . In other words, 10 percent of the changes in the mandatory disclosure index of the companies listed on the stock exchange can be explained by market value added.

Considering the value of S.E. in proportion to S.D., it can be claimed that regression line has been drawn well, and the dispersion of data is of low value. Durbin - Watson statistic, which is equal to 1.99, indicates that there is no autocorrelation in the model. In the above-mentioned model, the function of the test conducted on the sample $(\mathrm{F}=10.91)$ shows that the value of $\mathrm{F}$ at the alpha level of five percent is significant, and therefore, null hypothesis is rejected.

Considering the effective variables in the model and multivariate regression, it is inferred that the direction of the test is negative. According to the coefficient of determination $R^{2}$, distribution tends to zero. Therefore, the relation between market value-added and mandatory disclosure index of the companies listed on the stock exchange is insignificant. In other words, about 10 percent of the changes between the quality of disclosure and market value-added have been estimated.

\section{The summary results}

\subsection{The Results regarding the Main Hypothesis}

The results of fitting this model by accounting performance criteria, including the rate of return on equity and earnings per share are effective in the level of mandatory disclosure of information in the companies listed on the stock exchange. Considering the effective variables in the model and the use of multivariate regression, and according to the coefficient of determination, distribution $R^{2}$ tends to zero. Therefore, the relation of the rate of return on equity and market value-added with the mandatory disclosure index of the companies listed on the stock exchange is insignificant. In other words, around 10.6 percent of the changes between the quality of disclosure and the rate of return on equity and market value added have been estimated.

\subsection{The Results regarding the First Sub-Hypothesis}

The results of fitting this model by the rate of return on equity have positive effects on the level of mandatory disclosure of information in the companies listed on the stock exchange. Considering the effective variables in the model and the use of multivariate regression, the direction of the test is positive. According to the coefficient of determination, distribution $R^{2}$ tends to zero. Therefore, the relation between the rate of return on equity and the mandatory disclosure index of the companies listed on the stock exchange is insignificant. In other words, around 10.3 percent of the changes between the quality of disclosure and the rate of return on equity have been estimated.

\subsection{The Results regarding the Second Sub-Hypothesis}

The results of fitting this model through earnings per share indicate that there are some positive effects on the level of mandatory disclosure of information in the companies listed on the stock exchange. Considering the effective variables in the model and the use of multivariate regression, the direction of the test is regarded as positive. According to the coefficient of determination, distribution $R^{2}$ tends to zero. Therefore, the relationship between the earnings per share and the mandatory disclosure index of the companies listed on the stock exchange is insignificant. In other words, around 9.6 percent of the changes between the quality of disclosure and the earnings per share have been estimated.

\subsection{The Results regarding the Third Sub-Hypothesis}

The results of fitting this model through the ratio of market value to office value of company (QTOBIN) have indicated that there are some positive effects on the level of mandatory disclosure of information in the companies listed on the stock exchange. Considering the effective variables in the 
model and the use of multivariate regression, the direction of the test is regarded as positive. According to the coefficient of determination, distribution $R^{2}$ tends to zero. Therefore, the relationship between QTOBIN and the mandatory disclosure index of the companies listed on the stock exchange is insignificant. In other words, around 9.6 percent of the changes between the quality of disclosure and the ratio of market value to office value of company (QTOBIN) have been estimated.

\subsection{The Results regarding the Fifth Sub-Hypothesis}

The results of fitting this model through market value-added have positive effects on the level of mandatory disclosure of information in the companies listed on the stock exchange. Considering the effective variables in the model and the use of multivariate regression, the direction of the test is regarded as negative. According to the coefficient of determination, distribution of $R^{2}$ tends to zero. Therefore, the relationship between market value-added and the mandatory disclosure index of the companies listed on the stock exchange is insignificant. In other words, around 10 percent of the changes between the quality of disclosure and market value-added have been estimated.

\section{Conclusion}

In this paper, we have studied the effects of performance criteria (accounting, market and economy) on the quality of financial reporting in Iran. To evaluate the variable financial reporting quality, the scores given to each company have been applied based on the checklist introduced by Iranian Association of Certified Public Accountants and used for the disclosure of the information of the annual financial statements of companies.

The statistical population of this research consisted of the companies listed on Tehran Stock Exchange over the period 2006-2011. The results of the tests conducted on 99 companies indicate that there was a significant and positive relation between the rate of return on equity and the equality of financial reporting. There was also a significant and positive relation between earnings per share and the equality of financial reporting. However, there was no relationship between QTOBIN and the equality of financial reporting. Finally, our results indicate there was a significant and positive relation between market value-added and the equality of financial reporting.

\section{References}

Ahmed, K., \& Nicholls, D. (1994). The impact of non-financial company characteristics on mandatory disclosure in developing countries: the case of Bangladesh. The International Journal of Accounting, 29, 62-77.

Arzitoon, R. (2004). A Study of the Relation between the Characteristics of Functional and Financial Structure and the Information Disclosure Level of the Financial Statements of the Companies Listed on Tehran Stock Exchange. Unpublished Dissertation. Shahid Beheshti University (In Persian).

Jaggi, B., \& Law, P.Y. (2000). Impact of culture, Market forces and legal system on financial disclosures. The International Journal of Accounting, 35, 416-495

Khalid, A. (2006).The association between firm-specific characteristics and disclosure. Managerial Auditing Journal, 21(5), 476-496.

Malekian, E., \& Saghafi, A. (1997). The Comprehensiveness of Annual Reports and Financial Characteristics of the Companies listed on Tehran Stock Exchange. Journal of Accounting and Auditing Studies, 22, (In Persian).

Nikomaram, H., \& Badavar Nahandi, Y. (2009). Preparation of a model for determining and evaluating the factors effective in the quality of the financial reporting in Iran. Quarterly of Farasouye Modiriyat (beyond Management). $2^{\text {nd }}$ Year. 8, 141-187 (In Perisan). 
Seyed Abadi, M. R. (2004). A Study of the Financial Ratios and Size on the Full Disclosure of Information of the Companies Listed on the Stock Exchange. Mazandaran University (In Persian).

Shroedr. R. G., Myrtle, W. C., \& Cathey, J.M. (2009). Financial Accounting Theory and Analysis.

Tai, B. Y. K., Au-Yenug, P. K., Kowk, M. C. M., \& Lau, L. W. C. (1990). Non-compliance with disclosure requirements in financial statements: The case of Hong Kong companies. The International Journal of Accounting, 25(2), 99-112.

Wallace, R.S. Olusegun, K.N., \& Araceli, M. (1994). The relationship between the comprehensiveness of corporate annual reports and firm characteristics in Spain. Accounting and business research, 25(7), 41-53.

Wallace, R. S. O., \& Naser, K. (1995). Firm-specific determinants of the comprehensiveness of mandatory disclosure in the annual corporate reports of firms listed on the Stock Exchange of Hong Kong. Journal of Accounting and Public Policy, 14, 311-368

Wallace, R. S. O., Naser, K., \& Mora, A. (1994, winter). The relationship between the comprehensiveness of corporate annual reports and firm characteristics in Spain. Accounting and Business Research, 25(97), 41-53. 